\title{
¿Cómo se funda un convento? Algunas consideraciones en torno al surgimiento de la vida monástica femenina en Santa Fe de Bogotá (1578-1645)*
}

\section{Resumen}

La Corona española, en ejercicio del Patronato, era consciente de su obligación de sostener económicamente a la evangelización en las llamadas Indias Occidentales; ello implicaba también la fundación de conventos de frailes. No sucedía, sin embargo, lo mismo con los conventos de monjas, considerados más bien como "obras pías" que debían ser promovidas por laicos o por iniciativa de los obispos. En el presente artículo se analizará el proceso de apertura de tres conventos femeninos en el Nuevo Reino de Granada: Santa Clara (Tunja), Nuestra Señora de la Concepción y Santa Inés (Santa $\mathrm{Fe}$ ), que surgieron patrocinados por personajes poderosos para acoger a las hijas y huérfanas de conquistadores y pobladores. Estas iniciativas permiten vislumbrar, entre otros aspectos, la consolidación social de algunas familias a partir este tipo de estrategias que vinculaban las adhesiones religiosas y la economía en la primera mitad del siglo XVII. Desde el método histórico-crítico se analizarán los documentos que revelan los diferentes procesos fundacionales presentes en el Archivo General de Indias, Archivo General de la Nación (Colombia) y Archivo de las Monjas Dominicas de Santa Inés de Bogotá.

Palabras clave: monjas, conventos, órdenes religiosas femeninas, obras pías, Patronato, Audiencia de Santa Fe.

Referencia para citar este artículo: BRIZUELA MOLINA, Sofía Norma (2017). “¿Cómo se funda un convento? Algunas consideraciones en torno al surgimiento de la vida monástica femenina en Santa Fe de Bogotá (1578-1645)”. En Anuario de Historia Regional y de las Fronteras. 22 (2). pp. 165-192.

Fecha de recepción: 06/02/2016

Fecha de aceptación: 27/03/2017

Sofía Norma Brizuela Molina: Diplomada en Estudios Avanzados de Tercer Ciclo en el área de Conocimiento de Historia de América de la Universidad Pablo de Olavide, Sevilla, España. Licenciada en Historia, título expedido por la Facultad de Filosofía y Letras de la Universidad Nacional de Tucumán, Argentina. Miembro investigador del grupo de estudios sobre Religión, Sociedad y Política: Sagrado y Profano de la Universidad Industrial de Santander (UIS), Colombia. Correo electrónico: sobrizu@hotmail. com. Código ORCID: 0000-0002-9126-695X.

\footnotetext{
" La autora adelanta actualmente su tesis doctoral sobre el surgimiento de órdenes religiosas femeninas en el Nuevo Reino de Granada. Estas fundaciones, creadas en un espacio de medio siglo (1578-1645), se revelan como fundamentales para la consolidación de la sociedad colonial en diferentes puntos de la geografía de la actual Colombia. El estudio aborda los conventos de las Clarisas de Tunja y de Concepcionistas, Carmelitas y Dominicas en Santa Fe de Bogotá, cuatro órdenes que alentaron el surgimiento de los conventos en distintas ciudades. El artículo se centra en los procesos formativos de tres claustros, los estamentos sociales y la base económica que soportaron su funcionamiento inicial. Los directores de la tesis son el Dr. José María Miura Andrades y la Dra. Silvia Pérez González de la Universidad Pablo de Olavide de Sevilla adonde se defenderá la tesis en cuestión.
} 


\title{
How is a Convent Found? Some Considerations Around the Arise of the Femenin Monastic Life in Santa Fe de Bogotá (1578-1645)
}

\begin{abstract}
The spanish crown, with the control of the patronage, had the economical obligation of maintaining the evangelization of the new world; That also implied the establishment of abbeys. It wasn't the same with the womens' convents, considered 'pious works' which owe be promoted by the bishops and laymen. In this essay we analyzed the opening process of three femenine convents in the New kingdom of Granada: Santa Clara (Tunja), Nuestra Señora de la Concepción and Santa Inés (santafé). From the analysis of documentary sources we pretend to answer who were the founders, why did they decided to rise a women's convent, how much was the investment and how the opening was managed. Thus we pursue to highlight social strategies that associate the religious affiliations and the elites'economy between the late 16th and first half of the 17th century.
\end{abstract}

Keywords: Nuns, Convents, Femenine Religious Orders, Pious Works, Patronage, Santafés Audience.

\section{Como se funda um convento? Algumas considerações em torno ao surgimento da vida monástica feminina em Santa Fé de Bogotá (1578-1645)}

\section{Resumo}

A Coroa espanhola, no exercício do patronato, tinha a obrigação de sustentar economicamente a evangelização nas Índias; isso implicava também a fundação de conventos de frades. Não acontecia o mesmo com os conventos de freiras, considerados como "obras pias" que deveriam ser promovidas pela iniciativa dos bispos ou laicos. Neste artigo se analisou o processo de abertura de três conventos femininos no Novo Reino de Granada: Santa Clara (Tunja), Nossa Senhora da Conceição e Santa Inês (Santa Fe). A partir da análise de fontes documentais pretendemos responder quem eran os fundadores, por que decidiram fundar um convento de freiras, quanto se deveria investir na obra e como se gerenciava a abertura. Desta maneira procurou-se destacar estratégias sociais que vinculavam as adesões religiosas e a economia de membros da elite entre os finais do século XVI e a primeira metade do século VXII.

Palabras-chave: freiras, conventos, ordens religiosas femininas, obras pias, Patronato, Audiência de Santa Fe. 


\section{Introducción}

En el ambiente religioso que se vivía a ambos lados del Atlántico a finales del siglo XVI y primera mitad del XVII, pocas dudas existen sobre el gran interés que despertaba como meta de todo creyente el alcanzar la salvación eterna. Laicos o clérigos, todos parecían esforzarse por ganar el perdón de sus pecados. Este objetivo-si bien siempre presente en el cristianismo- constituyó un elemento motivador por el impulso que daba la "devotio moderna"1 movimiento espiritual que urgía a los creyentes a tener una vida virtuosa, que animó el surgimiento de comunidades religiosas en Europa especialmente en España y en los territorios americanos incorporados a la Corona.

En efecto, el Concilio de Trento, asumió estos principios e impulsó la práctica de las buenas obras como camino privilegiado para alcanzar los beneficios eternos. Desde esta perspectiva, se entiende el enorme interés de los fieles por materializar obras pías como la asistencia a los pobres, el otorgar limosnas, erigir capellanías, fundar cofradías, hospitales o monasterios de monjas en favor del aumento de la piedad y la fe en la comunidad. El acopio de estas buenas obras ayudaría al creyente, pues se aceptaba que éstas se computarían al final de su vida como parte de los esfuerzos (incluyendo su capital económico) invertidos para la obtención del favor divino: “[...] porque a los que obran bien hasta la muerte y esperan en Dios, se les debe proponer la vida eterna [...] ya como premio con que se han de recompensar fielmente según la promesa de Dios, los méritos y las buenas obras"2. En estrecha relación con esta concepción, la mencionada fundación de conventos femeninos ocupaba un lugar especial dentro de las obras llamadas pías. Estas iniciativas, como se verá, exigían grandes inversiones económicas a aquellos vecinos pudientes y piadosos, quienes a cambio obtenían reconocimiento de su condición de patronos. Consideramos que lo que motivaba a personajes encumbrados de la sociedad colonial a impulsar estas instituciones, trascendía la adhesión religiosa. Por un lado, el surgimiento de conventos para mujeres manifestaba la consolidación de las nacientes ciudades americanas, pues las fortunas particulares se invertían en beneficio de la propia clase o sociedad en estos territorios. Por otro lado, dichos conventos se trasformaban en núcleos de inversión de

\footnotetext{
${ }^{1}$ La Devotio Moderna, es un movimiento espiritual que surge a finales del siglo XIV como una contraposición a los caminos de la religiosidad y piedad que habían venido recorriendo desde siglos anteriores. Se originó en los países bajos. Los representantes en España fueron Vicente Ferrer (+1416) Torquemada (1468), y fundamentalmente el abad García Jiménez de Cisneros, primo del Cardenal Cisneros. La obra del abad tendrá gran influencia en los ejercicios espirituales de Ignacio de Loyola y se trata de una interpretación de la vida cristiana que rompe con el entramado de espiritualidad medieval. Se destacan prácticas como la interioridad, voluntarismo, ascética, se insiste en el esfuerzo de la voluntad más que de la gracia, la imitación de Cristo y la oración metódica. Estos aspectos serán asumidos por el Concilio de Trento y nutrirán los principios de la Contrarreforma que fue la reacción de la Iglesia a los embates de la Reforma protestante. Álvarez Gómez, Jesús. Historia de la Vida religiosa T. III. Desde la Devotio Moderna al Concilio Vaticano II (Madrid: Ediciones Claretianas. 2da ed, 2002), pp. 25-27. Sánchez Lora, Jose L. "Mujeres, conventos y formas de religiosidad barroca” (Madrid: Fundación Universitaria Española, 1988), pp. 29 y ss. Toquica, Constanza. A falta de oro: linaje, crédito y salvación. Una historia del Real convento de Santa Clara de Santa Fe de Bogotá siglos XVII y XVIII, Bogotá: Universidad Nacional de Colombia, Minst. de Cultura. Inst. Colombiano de Antropología e Historia, pp. 54-58.

${ }^{2}$ Sacrosanto y Ecuménico Concilio de Trento, Sesión VI, Capítulo XV (Barcelona: Imprenta de Benito Espona, 1845), p. 64.
} 
capital que buscaban asegurar la estabilidad económica de las familias a cargo de las fundaciones. En este artículo analizaremos los orígenes de tres conventos, el primero en Tunja en 1578 (Clarisas), que nos permite fijar quizás un esquema para comprender los otros dos: la Concepción (1595) y Santa Inés (1645). Nos interesa indagar las redes que se tejen tras estos propósitos y los montos económicos que se destinan a los claustros. Otros aspectos que nos ocuparán serán también las diferentes modalidades de participación en el patronato, así como la opción a adscribir al convento a una $\mathrm{u}$ otra Orden religiosa. Nos parece que una mirada de conjunto nos permitirá articular y conocer mejor los intereses e inversiones de esta sociedad colonial.

\section{Orígenes de la vida conventual femenina en el Nuevo Reino de Granada}

Por razones del Patronato ${ }^{3}$, la Corona española tenía obligaciones económicas para el sostenimiento de las órdenes y todo lo que implicara el esfuerzo para la evangelización de los territorios americanos. Los bienes materiales proporcionados por el rey con el objeto de garantizar la efectiva conversión de los indígenas a la fe católica, se traducían en ayudas para la construcción de conventos y misiones, además de salarios para curas doctrineros y otras ayudas como la asignación de partidas de vino, cera, aceite, entre otros destinos comunes ${ }^{4}$. Desde este punto de vista, la situación de los conventos de monjas era diferente a la de los religiosos. Al estar las mujeres inhibidas de la función sacramental $-\mathrm{y}$ en consecuencia inhabilitadas para la evangelización directa y la catequesis- la función de un monasterio de mujeres se restringía a su resguardo y clausura para una vida ofrecida a Dios en oración y observancia de los votos. Por esta razón, dichas instituciones no gozaron del mismo auxilio económico de los conventos masculinos. No obstante, algunos conventos de monjas fundados a lo largo de la geografía americana percibieron ayudas económicas del rey, aunque bajo consideraciones excepcionales y no siempre con regularidad.

\footnotetext{
${ }^{3}$ Respecto de este concepto numerosos autores trabajan el tema. En este caso citamos aquí a J.H. Elliot: "Por bula de 1486 el papado había concedido a la corona el "patronato» o derecho de presentar todos los obispados y beneficios eclesiásticos en el reino morisco de Granada. En 1508 Fernando aseguró para los gobernantes de Castilla a perpetuidad el derecho de organizar la Iglesia y presentar los beneficios en sus territorios de Ultramar [...] El efecto del patronato fue el de dar a los monarcas de Castilla en su gobierno de las Indias un grado de poder eclesiástico del que no había precedente europeo, fuera del Reino de Granada. Ello permitió al rey aparecer como el Vicario de Cristo y disponer los asuntos eclesiásticos en Indias según su propia iniciativa sin interferencia de Roma. No se permitió a ningún nuncio papal poner los pies en Indias ni tener ninguna comunicación directa con ellas, y todos los documentos que fuesen en cualquier dirección entre Roma y el Nuevo Mundo necesitaban la aprobación previa del Consejo de Indias. [...] El poder eclesiástico de la corona en Indias era en efecto, absoluto con derechos teóricos afianzados por un control total del patronazgo", en Bethell, Leslie (ed). "Historia de América Latina”, en América Colonial: Europa y América en los siglos XVI, XVII, XVIII, capítulo I, pp. 13-14.

${ }^{4}$ De la Corte Navarro, Inmaculada. "Aportaciones reales a los conventos de monjas", en Memorias del II Congreso Internacional del Monacato femenino en el Imperio español (México: Centro de Estudios de Historia de México, 1995), p. 138
} 
En el caso de Santa Fe, se tiene noticia de una petición para la fundación de un convento en una carta del Cabildo en febrero de $1577^{5}$; en la misma, entre otros temas, se trataba la herencia legada por el vecino Cristóbal Rodríguez con esa finalidad. Para entonces, la ciudad de Santa Fe, aunque fundada en 1538, fungía ya como sede de la Audiencia y cabeza de obispado; consecuentemente, junto a las principales autoridades, ya se habían establecido también los conventos de las órdenes mendicantes de dominicos y franciscanos. La iniciativa del vecino, confirmaba el éxito relativo de los recientes procesos de conquista, poblamiento y control de territorio. La erección de un primer convento de monjas en Santa Fe, sin embargo, no se produjo sino hasta 1595 y se justificó aduciendo la necesidad de albergar a las viudas de conquistadores y encomenderos, así como a otras mujeres solteras españolas o criollas. En ese contexto, estas instituciones respondían a necesidades sensibles de la temprana organización de las ciudades donde se habían completado los procesos de conquista e iniciado la primera evangelización. Se agregaba a ello la preocupación sincera de algunos por las mujeres que no contaban con el resguardo social del matrimonio ${ }^{6}$.

Al respecto resulta útil establecer un modelo de fundación a partir del surgimiento del primer monasterio femenino en el Nuevo Reino de Granada en 1578 en Tunja, por el capitán Francisco Salguero y su mujer Juana Macías de Figueroa ${ }^{7}$. De esta primera experiencia se destacan algunas pautas que serán comunes en las siguientes fundaciones de conventos en el Nuevo Reino. Así, en las primeras diligencias previas a la apertura, el mencionado fundador justificaba ante el Consejo de Indias que un monasterio de monjas resolvería la situación de pobreza en la que se inscribían varias mujeres de familias notables para quienes, por no contar con recursos para una buena dote, no podían acceder a un buen matrimonio ${ }^{8}$. Se evidencia aquí, por un lado, el carácter de estas alianzas matrimoniales, concebidas para que los contrayentes sumaran beneficios económicos como tierras, encomiendas, minas, entre otros bienes. Sin embargo, ello no siempre era posible: la disponibilidad de hombres ricos no alcanzaba a cubrir el número de doncellas aptas para el matrimonio. Se entiende, entonces, cómo las mujeres con mayor probabilidad de nupcialidad eran aquellas que contaban con abultadas herencias. Dentro de estas se destacaban, por cierto, las viudas que agregaban a su capital familiar lo legado por el marido difunto9; ello suponía una concentración económica considerable como observó Germán Colmenares para la misma Tunja donde gran número de encomiendas pasaron, gracias a las viudas de los conquistadores, a un segundo marido ${ }^{10}$.

\footnotetext{
${ }^{5}$ Archivo General de Indias (en adelante AGI) Cabildos seculares: Audiencia de Santa Fe. SANTA_FE, 60, núm. 26.

${ }^{6}$ Neukirchen Petra. "Aproximación jurídica a los derechos de las mujeres en contratos matrimoniales", en López Cordón, María Victoria y Carbonell, Esteller Montserrat (eds.), Historia de la mujer e historia del matrimonio. Seminario familia, elite y poder en el reino de Murcia siglo XV-XIX (Murcia: Universidad de Murcia, 1997), p. 140

${ }^{7}$ El convento se fundaría finalmente en 1578 no obstante, la documentación previa data desde 1572.

${ }^{8}$ AGI: SANTA_FE, 124, núm. 8. 1574. Informaciones de oficio y parte: Francisco Salguero, vecino de Tunja.

${ }^{9}$ Gonzalbo, Aizpuru. Familia y orden colonial (México: El Colegio de México, 1997), p. 71

${ }^{10}$ Pasaron a segundas nupcias las encomiendas de los primeros maridos: Catalina Pinedo, Elvira Zambrano, María de Monsalve, Catalina Carvajal, Constanza Rodríguez Hermoso, María de la Hoz y Berrío, Isabel
} 
Por otro lado, se percibe detrás de estas estrategias matrimoniales cierta obsesión por preservar la pureza y el honor de los linajes. A los conquistadores y sus descendientes inmediatos parece preocuparles la probabilidad del mestizaje en los enlaces de las mujeres de sus familias; en últimas, incluso, preferían enaltecer "a algún inmigrante reciente o algún aventurero afortunado"11 para concertar un matrimonio que, aunque no fuese del todo provechoso, en su lógica resultara por lo menos honorable.

Resalta, igualmente, entre las motivaciones que llevaron al capitán Salguero a fundar este monasterio, el hecho de no tener descendencia. Su esposa, con permiso del obispo en el año 1573, decidió enclaustrase y tomar el hábito de Santa Clara. Según encontramos en la obra de Florez de Ocáriz, los frailes franciscanos estaban tras esta fundación, instruyéndola en la espiritualidad y regla de su orden ${ }^{12}$. Para fundar el monasterio, el capitán Salguero dispuso de sus bienes, entregando su propia casa y la encomienda del pueblo de Mongua: “[...] daba toda su hazienda e indios de encomienda que tiene en la dicha ciudad de Tunja que será de 350 indios poco más o menos"13. Asimismo, dada la relevancia de una obra de este tipo y considerando que se trataba del primer monasterio en el Nuevo Reino de Granada, se solicitó al rey que la encomienda fuese a perpetuidad para beneficio del monasterio, así como 3.000 pesos "de buen oro de renta” por año, también a perpetuidad, en "indios vacos" o de los que pertenecían a la Caja real. En la petición se aclaraba, además, que si en un caso no se pudiera disponer del dinero de los indios del rey, que se le traspasen entonces los beneficios de una encomienda del adelantado Jiménez de Quesada, que pertenecía también a la jurisdicción de Tunja, una vez que concluyera el término por el que se había establecido su usufructo.

Para el sustento de cosas menudas del monasterio, se pidió además que los indios del mismo adelantado le entregaran, de sus tierras y producción, unas 200 arrobas de sal, 100 arrobas de pescado y 100 múcuras $^{14}$ de miel de media arroba cada una. Se incluía en la petición, por último, tierras para trigo y ganado en la misma Tunja para el abastecimiento de las monjas, así como que la corona subsidie el viaje de cuatro o cinco monjas desde la península "[...] para que ordenen las cosas del monasterio y hagan las demás cosas necesarias y convenientes para la buena doctrina de las otras monjas"15. Dado el carácter pionero de la institución en el Nuevo Reino, se solicitó ayuda al rey para su fundación. Se preveía que el monto dispuesto para su funcionamiento provendría fundamentalmente de las encomiendas y recursos señalados. El nuevo convento fundamentaría su existencia en el modelo económico que se implanta en la

Maldonado, Catalina Valero, Isabel Ruiz. Colmenares, Germán. La provincia de Tunja en el Nuevo Reino de Granada (1539-1800) (Bogotá: Universidad de los Andes, 1970), p. 35.

${ }^{11}$ Ibid.

${ }^{12}$ Flórez de Ocáriz, Juan. Genealogías del Nuevo Reino de Granada [Libro I]. Joseph Fernández de Buendía. Impresor de la Real Capilla de su Magestad. Madrid. 1674. Libro I, p. 170. En la cita se ha respetado, la ortografía original del texto, criterio que se sigue en lo sucesivo.

${ }^{13}$ AGI. SANTA_FE, 124, núm. 8.1 R, Informaciones de oficio y parte: Francisco Salguero, vecino de Tunja. Fecha final $157 \overline{5}$. La ortografía original del documento se ha respetado.

${ }^{14}$ Vasija de origen precolombino, de barro arcilloso similar a la botija, de tamaño mediano, con largo y estrecho cuello y pie esferoide usada para recoger, beber y almacenar agua, chicha o cereales.

${ }^{15}$ Ibid. $2 \mathrm{~V}$ y $3 \mathrm{R}$. 
región con el proceso de conquista, basado en la tenencia de indígenas y su explotación como mano de obra. Lo único que se solicitó a la Corona fue el desembolso para el viaje de cuatro o cinco monjas, merced que finalmente no se concedió.

Los monasterios fundados en el territorio del Nuevo Reino de Granada hacia la primera mitad del siglo XVII (ver el Cuadro 1.), contaron con la iniciativa "secularepiscopal" 16 pues, aunque en su mayoría fueron fundados por laicos los respectivos obispos secundaron las propuestas. Las Ordenanzas de Indias relativas a las casas religiosas prescribían que los obispos dieran la primera licencia e informaran al rey sobre la pertinencia de estas fundaciones ${ }^{17}$. Asimismo, señalaban que los prelados debían velar por todo aquello que beneficiara a la fe, evangelización y necesidades de sus propias diócesis; para ello, por lo general, debían disponer su patrimonio económico. Con ese criterio, se entendía que ofrecer resguardo a determinadas mujeres, era atender una necesidad social a la que la Iglesia debía vigilar. Asumir estas empresas, implicaba una alta inversión de dinero y junto a las gestiones episcopales, no faltaron las de laicos que destinaron sus capitales económicos, involucrando a sus familias y descendencia en la tarea de proveer y custodiar un convento.

Cuadro 1. Fundación de Conventos en la Audiencia de Santa Fe, 1578-172918.

\begin{tabular}{|c|c|c|c|}
\hline Orden & Ciudad & Año & Fundadores \\
\hline Clarisas & Tunja & 1578 & Laicos \\
\hline Clarisas & Pamplona & 1584 & Laicos \\
\hline Clarisas & Cartagena & 1617 & Fraile franciscano \\
\hline Concepcionistas & Santa Fe & 1595 & Laico \\
\hline Concepcionistas & Tunja & 1599 & Laicos y clérigo \\
\hline Carmelitas & Santa Fe & 1606 & Laicos \\
\hline Clarisas & Cartagena & 1617 & F. Franciscano \\
\hline Carmelitas & Cartagena & s/f & s/d \\
\hline Clarisas & Mérida ${ }^{19}$ & 1626 & Clérigo y Laico \\
\hline Clarisas & Santa Fe & 1629 & Obispo \\
\hline Carmelitas & Villa de Leiva & 1634 & Laicos \\
\hline Dominicas & Santa Fe & 1645 & Laicos \\
\hline
\end{tabular}

Fuente: Florez de Ocáriz, Juan. Genealogías del Nuevo Reino de Granada [Libro I]. Joseph Fernández de Buendía. Impresor de la Real Capilla de su Magestad. Madrid. 1674. Libro I.

\footnotetext{
${ }^{16}$ Plata Quezada, William. Vida y muerte de un convento. Dominicos y sociedad en Santafé de Bogotá (Colombia) siglos XVI-XIX (Salamanca: San Esteban Editorial, 2012), pp. 130-134.

${ }^{17}$ Recopilación de Leyes de los Reynos de las Indias, Libro I, Título III. "De los Monasterios de Religiosos y Religiosas hospicios y recogimientos de huérfanas", Julián de Paredes [Impresor], Madrid, http:// fondosdigitales.us.es/fondos/libros/752/14/recopilacion-de-leyes-de-los-reynos-de-las-indias/.

${ }^{18}$ Se anota en el presente cuadro la información que proporciona Florez de Ocáriz. Para completar el listado de monasterios en el actual territorio de Colombia faltarían registrarse las Concepcionistas de Pasto en 1588, Agustinas de Popayán 1578 y Carmelitas de Popayán 1729.

${ }^{19}$ Pertenecía a la Audiencia del Nuevo Reino de Granada.
} 
Fundar una institución religiosa, ya sea una iglesia o convento, exigía estas cuatro condiciones: disponer de un solar para fundar la iglesia o convento, construir el recinto, dotarlo para su funcionamiento y garantizar económicamente la obra con bienes o rentas. En sentido estricto se llamaba fundador al donante de la propiedad. Leticia Sánchez Hernández trabaja este tema y dice que "[...] fundar hace referencia tanto a la construcción de un edificio como a la constitución de una institución de cualquier índole encaminada a cumplir unos objetivos concretos" ${ }^{20}$. Si el fundador, además de donar el predio, también construía y dotaba las instalaciones del convento, se hacía merecedor del reconocimiento al derecho patronal ${ }^{21}$. Nuevamente Sánchez Hernández explica que el término patronato "[...] se refiere al derecho o poder que ejerce una persona -el patrón o la patrona- sobre una corporación o fundación generalmente de carácter pío con la obligación de cumplir determinados deberes con ella"22. Estas dos cuestiones pueden coincidir en una sola entidad tal como sucedió en el Nuevo Reino de Granada al momento de efectuarse la fundación de los conventos. En los tres monasterios que analizamos en el presente trabajo, la entrega de los bienes les implicó a los fundadores traspasar sus propiedades a las respectivas fundaciones. Los principios que motivaron estas acciones respondían a la piedad, sin embargo, estos gestos les devolvían a los donantes reconocimiento social, prestigio y consolidación del status. Un ejemplo claro lo podemos encontrar Luis López Ortíz, patrón-fundador del convento de la Concepción de Santa Fe, quien en 1594 dispuso de los principales asientos de la capilla del convento que iba a fundar como privilegio de sus descendientes (en su mayoría mujeres):

[...] asi se an de sentar las mujeres del linaje de López Ortíz que fueren a la mano derecha de la capilla mayor a las partes de la epístola, porque el asiento de la mano del Evangelio a de ser para el $\mathrm{Sr}$ arzobispo y presidente del rreino ${ }^{23}$.

Efectivamente, en los recintos religiosos levantados por donantes y fundadores, las prerrogativas en la ocupación del espacio se regulaban de manera tal que quedara establecida la diferencia entre las mujeres de la familia del fundador o patrón y el

\footnotetext{
${ }^{20}$ Sánchez Hernández, María Leticia. "Servidoras de Dios leales al Papa. Las monjas de los monasterios reales", en librosdelacorte.es, Monográficos 1, Año 6, 2014, ISSN 1989-6425. Sobre este tema: Levaggi, Abelardo. "Papel de los patronos en las capellanías. Cuestiones suscitadas a su respecto en el río de la Plata”, en Martínez López-Cano, Pilar, Von Wobeser G. Muñoz, Juan Guillermo (coords.), Cofradias Capellanías y Obras Pías en la América Colonial (México, 1998), p. 143.

${ }^{21}$ Patronato: “[...] es el derecho de presentar sugeto para que se le confiera algún beneficio o bien, un derecho honorífico, oneroso y útil que compete a uno o a una iglesia por haberla fundado, construido o dotado con consentimiento del obispo o por haberle heredado de sus predecesores que lo hicieron". Escriche Joaquín. Diccionario razonado de legislación y jurisprudencia. Librería de Rosa y Bouret (París, 1852), Voz: Patronato, p. 1334. "Se trata de un derecho honorífico (no de estricta justicia), oneroso y útil (conjunto de privilegios) que por concesión de la Iglesia compete a los fundadores, o a sus causahabientes, sobre una iglesia, capilla, beneficio, monasterio, etc.". Teruel Gregorio de Tejada, Manuel. Vocabulario básico de la historia de la Iglesia (Barcelona: Crítica, 1993), p. 38. Voz: Patronato, p. 352

${ }^{22}$ Sánchez Hernández, María Leticia, Op Cit., p. 295.

${ }^{23}$ Archivo General de la Nación [Colombia] (en adelante: AGN). Sección Colonia. CapellaníasCundinamarca. Expediente relacionado con el expediente y capellanía que don Luis López Ortíz fundó a favor del Monasterio de las Monjas de la Concepción en Santafé, del cual fue fundador. Folios: 714-751. 1594-1599. CAPELL-C/MARCA SC.9, 1, D. 24. 728v
} 
resto de la comunidad. La ubicación cercana al altar en la distribución de los asientos asimilaba al patrón con las principales autoridades del gobierno civil y eclesiástico. Un privilegio al que se agregaba también el de poder disponer del espacio de la capilla para él y sus descendientes:

\begin{abstract}
Y manda y es la voluntad de Luis López Ortíz que en la vobeda de la dha capilla mayor se puedan enterrar a todos sus deudos en consanguinidad y afinidad y ninguna otra persona ni se pueda dar licencia para ello por ser patrón ni aya de ninguna otra persona fuera de ellos ${ }^{24}$.
\end{abstract}

La importancia de contar con la capilla del convento para uso funerario de la familia de López Ortíz sería, además de un privilegio, uno de los principales objetivos de la creación del convento. Con este tipo de obras se buscaba, entre otras cosas, garantizar los beneficios espirituales inherentes a las ventajas que otorgaba un sitio preferencial en el espacio sagrado, en el que además se dispensarían misas y rezos por sus almas. Una prerrogativa que aseguraba su salvación o, al menos, les ofrecía mayores garantías para ese fin. Hasta hoy, si se visita la Iglesia de la Concepción en Bogotá, puede leerse en la piedra de la entrada: "Aqui yace Luis López Ortíz, vecino de esta ciudad el menor hombre del mundo y en pecados el mayor, esperando la misericordia de Dios". ${ }^{25}$ Se advierte en esta mentalidad y práctica piadosa, de un lado, el temor a perder la salvación y, de otro, la búsqueda del reconocimiento a los esfuerzos para ganarla. El acopio de méritos, en principio, tenía como finalidad flexibilizar el designio divino. Se entendía, por ende, que el triunfo radicaba en una vida virtuosa, asegurada además por las oraciones de sus descendientes a fin de obtener la intercesión por los pecados. Desde esta perspectiva la misa, por ejemplo, se revela como un acto fundamental para alcanzar la vida eterna, entendiéndose que, a mayor número de celebraciones litúrgicas, mayores sufragios se alcanzaban. Todo dinero destinado a los oficios en nombre del difunto, resultaba entonces una buena inversión. Similares efectos se esperaban de las obras pías.

\title{
"Bajo el título de la Concepción de Nuestra Señora": el primer convento de Santa Fe
}

El primer convento de mujeres de Santa Fe de Bogotá abrió sus puertas en septiembre de 1595. Sin embargo, el interés vecinal por construir un recinto que albergara a las "hijas huérfanas de conquistadores y principales" -como se ha dicho- se había planteado ya en 1577 en una carta del cabildo de la ciudad para destinar a este fin la herencia legada por el comerciante Cristóbal Rodríguez ${ }^{26}$.

Efectivamente, el cabildo elevó la petición, solicitando además al rey solventar la obra con las medias anatas de las encomiendas, haciendo constar que el mencionado vecino

\footnotetext{
${ }^{24}$ AGN. Ibid. CAPELL-C/MARCA: SC.9, 1, D.24. 729 r.

${ }^{25}$ La iglesia se encuentra en el centro de Bogotá, en la Carrera $9^{\mathrm{a}}$ con Calle $10^{\mathrm{a}}$.

${ }^{26}$ AGI. JUSTICIA, 1109. Autos entre partes. Santa Fe. (1575/1576)
} 
¿Cómo se funda un convento? Algunas consideraciones en torno al surgimiento de la vida...

[...] dexo mucha parte de su herencia para que en esta ciudad se haga un monasterio de monjas...obra muy buena e muy necesaria por aver en esta ciudad muchas doncellas hijas de conquistadores de ese rreino muy pobres que entraran a servir a Dios ${ }^{27}$.

Al respecto, el citado texto de Florez de Ocáriz ${ }^{28}$ reitera, en lo relativo a las fundaciones de conventos en el Nuevo Reino Granada, que la herencia de Cristóbal Rodríguez constituyó el primer donativo para esta fundación:

Cristóbal Rodríguez Cano, vecino de la ciudad de Santafé, mandó en su testamento fundar en ella de su hazienda un convento de monjas de Santa Clara, con advocación de Santa Ana de Cano, nombrando por patrón a su sobrino Juan Rodríguez Cano y sus sucesores, si residiesen en esta ciudad, y sí no a Luis López Ortiz ${ }^{29}$.

Los fondos dispuestos en el testamento - un total de "once mil pesos de oro de veinte quilates"- al parecer no resultaron suficientes. Por esta razón, los mencionados Juan Rodríguez y López Ortíz ${ }^{30}$ se asociaron y aunaron un capital para el patronato. El monasterio se fundaría en honor de Santa Clara, iniciándose su obra en 1583. La muerte de Juan Rodríguez, sin embargo, decidió otro destino para el convento. El dinero disponible se redujo a ocho mil pesos, suma insuficiente para cubrir una obra de esas características. Pese a ello, Ortíz continuó solo con el patronato, aunque ya no bajo la advocación de Santa Clara, sino bajo "el título de la Concepción de Nuestra Señora". ${ }^{31}$

Luis López de Ortíz, comerciante originario de Plasencia, había llegado a Santa Fe en 1549 con 30 años de edad. ${ }^{32}$ Descrito por Florez de Ocáriz como "persona seglar de buena vida", invirtió en numerosas obras pías y finalmente destinó gran parte de su fortuna en la fundación de un convento de monjas. En efecto, se trataba de un hombre devoto quien consideraba tener una gran deuda con Dios, después de salvarse sin mayores consecuencias de la embestida de un toro bravo cuando estaba en su tienda -sita al lado de la catedral y al frente de la plaza mayor donde se lidiaban los toros-. Ello lo llevó a convertirse en benefactor de la iglesia de los agustinos, donando una imagen de la Virgen de Altagracia que mandó traer de España ${ }^{33}$. Sin embargo, como se verá, su principal obra fue destinar parte significativa de su patrimonio económico a la fundación del monasterio dedicado a la Virgen de la Concepción.

\footnotetext{
${ }^{27}$ AGI. Cabildos seculares: Audiencia de Santa Fe. SANTA FE,60, núm.261r

${ }^{28}$ Flórez de Ocáriz, "Genealogías del Nuevo Reino de Granada” Libro I, Joseph Fernández de Buendía, Impresor de la Real Capilla de su Magestad. Madrid. 1674 Libro I, pp. 171.

${ }^{29}$ Ibid.

${ }^{30}$ Flórez de Ocáriz, Juan, Op Cit., p.139

${ }^{31}$ Ibid.

${ }^{32}$ AGI. Contratación, 5217 a núm. 5, R.4 Expediente de información y licencia de pasajero a Indias de Luis López Ortiz, natural de Plasencia, con su criado Hernán González, natural de Zafra, al Nuevo Reino de Granada

${ }^{33}$ Flórez de Ocáriz, Juan, Op Cit, p. 236
} 
Se aprecia en esta experiencia fundacional cómo de una advocación se pasaba a otra. Más importante resulta el consecuente cambio de orden religiosa y de regla que ello conlleva, aspecto que parece no haber preocupado en mayor medida a los fundadores. En el caso de Luis López Ortíz, este cambio bien podría deberse a las preferencias de su devoción privada ${ }^{34}$; sin embargo, detrás de este hecho se advierte la franca expansión que entonces suscitaba el culto a la Virgen de la Inmaculada Concepción. A pesar de no existir una declaración de la iglesia romana sobre este atributo de la Virgen, existía ya una adhesión popular a la Concepción Inmaculada. Significativo también que, entre finales del siglo XIV y principios del XV, en la misma Corte de Castilla, haya surgido una orden religiosa femenina bajo este nombre de la Pura Concepción de la Virgen que incluso sería la primera en fundarse en territorio americano ${ }^{35}$. Para este tiempo, la devoción a la Virgen María Inmaculada nutría el clima religioso en la península, especialmente en Sevilla, desde donde se promocionaba no sólo el culto sino también su iconografía. Al respecto, como muestran Enriqueta Vila y Guillermo Lohmann, resulta ilustrativo el caso de los hermanos Almonte, comerciantes de Sevilla; uno de ellos, prior del Consulado de esa ciudad y fundador del Consulado de Lima, en reconocimiento a su labor fue retratado "[...] a los pies de la Inmaculada, patrona del Consulado con túnica blanca y manto azul." ${ }^{36}$ Puede intuirse que la vinculación comercial de López de Ortíz con Sevilla, así como la consentida difusión de esta expresión religiosa, promovió la consolidación de esta devoción en la ciudad de Santa Fe; curiosamente, esta devoción tendría su primer lugar de culto en una capilla fundada por un devoto mercader antes que por el auspicio de la Orden franciscana, tradicionalmente su promotora principal.

Para continuar con el proyecto, López Ortíz solicitó ayuda al presidente de la Audiencia, Antonio González. Este dispuso de los fondos que el rey había ordenado de las medias anatas ${ }^{37}$ producidas por las nuevas encomiendas, originalmente destinados

\footnotetext{
${ }^{34}$ Mantilla, al hacer una semblanza del fundador López Ortíz, cita a un manuscrito del convento de las concepcionistas en el archivo de la provincia franciscana de Santa Fe (37), que el comerciante dilucidando, qué nombre pondría al convento, tuvo una visión de "una matrona con el alba de la Concepción" en su propia casa lo que lo llevó a decidirse por la dicha advocación. Matilla, Luis Carlos. Las Concepcionistas en Colombia. (1588-1990) (Bogotá: Editorial Kelly, 1992), p. 39.

${ }^{35}$ El obispo de la Ciudad de México Juan de Zumárraga, dio el hábito concepcionista a cuatro beatas reclutadas en España por el franciscano Antonio de la Cruz. Habían llegado hacia 1530 y durante diez años se dedicaron a la instrucción cristiana de las hijas de los caciques. Hacia 1552 ya estaba fundado el monasterio iniciando un rápido proceso de expansión. Huerta Ourcel, Magdalena y Sarabia Viejo, María Justina. "Establecimiento y expansión de la orden concepcionista en México; siglo XVI", en La Orden Concepcionista. Actas del I Congreso Internacional (León, 1990), pp. 463-474

${ }^{36}$ Lohmann Villena, Guillermo y Vila Vilar, Enriqueta. "La emigración familiar a América, los Almonte", en Gonzalbo Aizpuru Pilar (coord.), Familias Iberoamericanas, Historia Identidad y Conflictos (México: Colegio de México, 2001), p. 51.

${ }^{37}$ Derecho exigido por la Iglesia en la provisión de beneficios no consistoriales, equivalente a las rentas del primer año de su posesión. Bonifacio IX en vista de las quejas generalizadas de las cortes europeas, redujo la tributación a la mitad (medias anatas). Para el caso americano, en razón del ejercicio del patronato por cédula real de 1631 y 1632, se creó el impuesto sobre medias anatas que tenía por objeto someter a tributación los empleos retribuidos y las mercedes de todo tipo. El derecho de media anata se devengaba una sola vez, cuando el interesado entraba en posesión de la merced en cuestión. La deuda tributaria consistía en la mitad de lo que el empleo retribuido al que estuviese vinculado al beneficio rentase en un año. Teruel
} 
¿Cómo se funda un convento? Algunas consideraciones en torno al surgimiento de la vida...

a la construcción del hospital de San Pedro. Se contó entonces con "once mil pesos que se pusieron en renta para el sustento de las monjas", así como con mil ducados aportados por el rey para la construcción de los muros, más el capital de López Ortíz ${ }^{38}$. Conforme a lo que encontramos en su testamento, se entregaron para el sostenimiento del convento "propiedades, censos y oro"39. En lo que respecta a la inversión que llevó el edificio, se cita en el testamento la referencia de los oficiales que tuvieron a cargo la construcción, quienes declararon que la obra concentró más de "50.000 p. de oro corriente" 40 . Así, finalmente, el convento se inauguró el 29 de septiembre de 1595.

El primer claustro para mujeres de la ciudad contaba no solo con el beneplácito de la Corona, sino también con su apoyo económico. Y aunque éste parece no haber sido permanente, hay constancia de una petición a la real ayuda ante algunos problemas surgidos en el edificio. Lo deducimos por un informe de 1618, en el cual el presidente de la Audiencia expresaba el buen destino del desembolso real: "Y la dha gracias y limosna, será obra digna de las grandezas, liberalidad y piedad christiana de V m y muy bien empleadas en dho convento"41.

La ayuda real, al menos en el momento de su fundación, y la herencia legada por su fundador, fallecido en $1597^{42}$, consolidaron a esta institución religiosa al que ingresaron tres mujeres españolas: Catalina de Céspedes, Úrsula de Villagómez e Isabel Campuzano ${ }^{43}$, hermanas del Fiscal de la Cancillería Real, Aller de Villagómez ${ }^{44}$. Este dato es de gran importancia porque al poco tiempo de morir López de Ortíz, el monasterio comenzó a tener graves problemas con los patronos sucesores. No conocemos efectivamente cuál ha sido el problema, pero se menciona una agresión física a la abadesa Beatriz de la Concepción ${ }^{45}$ por parte de uno de los familiares. Esto

Gregorio de Tejada, Manuel, Op Cit., p. 17; Aldea Vaquero, Quintín; Marín Martínez, Tomás; Vives Gatell, José. Diccionario de Historia eclesiástica de España. España (Madrid: Instituto Enrique Flórez, CSIC, 1973), p. 61. Mayoralgo y Lodo, José Miguel. Historia del régimen jurídico de los títulos nobiliarios. Manual de Nobiliaria I (Madrid: Ed. Hidalguía, 2007), p. 186.

${ }^{38}$ Flórez de Ocáriz, Juan, Op Cit., p. 139

${ }^{39}$ AGN: CAPELL-C/MARCA: SC.9,1,D. 24 Expediente relacionado con el expediente y capellanía que don Luis López Ortíz fundó a favor del Monasterio de las Monjas de la Concepción en Santafé, del cual fue fundador (1594/1599) fs 716r.

${ }^{40}$ Ibid., AGN. CAPELL-C/MARCA: SC.9, 1, D. 24

${ }^{41}$ AGI. SANTA_FE, 131, núm. 5, 5v. Informaciones: Monjas del convento de Nuestra Señora de la Concepción. (1618)

${ }^{42}$ Ibid., $4 \mathrm{r}$.

${ }^{43}$ AGI. CONTRATACION, 5245, núm. 1, R.1 Expediente de información y licencia de pasajero a Indias de Ursula Campuzano, hija de Antonio de Astorga Campuzano y Beatriz de Tineo, con su hermana Isabel Campuzano, naturales de León, al Nuevo Reino de Granada. La llegada de estas mujeres al Nuevo Reino de Granada es en 1594. Úrsula como de cuarenta años e Isabel de 32.

${ }^{44}$ AGI: CONTRATACION, 5246, núm. 1, R.28. A principios de 1594, Aller de Villagómez, llegó con su mujer Mencia de Avila y sus hijos: Alonso Villagómez y Esteban, como fiscal de la Real Audiencia del Nuevo Reino de Granada. En 1602 fue promovido como Fiscal a la Audiencia de Nueva España.

${ }^{45}$ Mantilla, Luis C., Op Cit., p. 64. De Beatriz de la Concepción trataremos más adelante porque es protagonista principal de la otra fundación que aquí analizamos. 
motivó a que el fiscal Villagómez, interpusiera un pleito para que se modificara la titularidad del convento y se le reconociera al rey el título de patrón. La sentencia salió favorable al fiscal por lo que el convento quedó bajo el patronato real y ya sólo como fundadores, Ortíz y sus descendientes ${ }^{46}$.

La titularidad real del patronato ${ }^{47}$, además del reconocimiento de la dotación efectuada por la Corona, daba relevancia a la buena voluntad del monarca para con sus súbditos y hacían destinatario a la persona del rey de los beneficios espirituales que generaban las obras pías. Sin embargo, cabe interrogarse aquí si la prerrogativa del patronato real le resultó favorable al convento. En principio, debería haberle garantizado mayor autonomía económica al no estar sujeto a una familia sino a la Corona misma. Este aspecto podría explicar la prosperidad y las importantes actividades financieras que este convento sostuvo a lo largo del siglo XVII ${ }^{48}$.

Desde esta perspectiva, en efecto, queremos mencionar la "funcionalidad económica"49 que tuvieron los conventos femeninos durante el periodo colonial en las diferentes economías regionales; particularmente porque una de sus principales funciones fue la de otorgar créditos, práctica a la que también se dedicaban otras instituciones eclesiásticas como las capellanías ${ }^{50}$. En este caso, el monasterio de la Concepción

\footnotetext{
${ }^{46}$ Flórez de Ocáriz, Juan, Op Cit., p. 171. Mantilla cita una denuncia de las monjas a la Audiencia (AGNC. Fondo Bernardo J. Caycedo. Caja 15 doc.7) en la que se hace un reconocimiento del aporte entregado por la Corona a efectos de modificar la titularidad del patronato. En dicho informe, se dice que se probó que el rey había gastado más de 14.000 p. de oro de a veinte quilates, que la mitad de la propiedad donde se emplazaba el convento se obtuvo del donativo de Juan Rodríguez Cano y la otra mitad fue el resultado de la suma de las dotes de las religiosas. Asimismo, se indicó que los gastos de médico, botica, cera, aceite y vino procedían de las mismas dotes que para 1618 no se contaba con ninguna renta legada por Luis López Ortíz.

${ }^{47}$ Además del Patronato universal que ostentaban los reyes de España sobre la Iglesia, el patronato real podía referirse al vínculo especial establecido con fundaciones concretas realizadas por ellos. Los reyes podían ser patronos de una capilla, monasterio, hospital o cualquier obra pía en función de que lo eran de todas las iglesias del Reino. Asimismo, podían constituirse en patronos particulares cuando por iniciativa propia y con su hacienda dotaban un instituto religioso. Sánchez, María Leticia, Op Cit., pp 295-296. Respecto del caso de la Concepción, se argumenta en el pleito el dinero aportado por el Rey para modificar la titularidad del patronato. Mantilla, Luis C., Op Cit., p. 65.

${ }^{48}$ Actualmente se están realizando valiosos estudios del Convento de la Concepción de Bogotá y su destacada incidencia en la economía santafereña colonial que seguramente darán profundidad a estas temáticas. Castro Vargas, Hernando. "Jerarquías sociales y relaciones políticas, el convento de la Concepción de Bogotá y la ejecución de censos (1739-1810)", en Revista Republicana, núm. 8, enero-junio, Centro de Investigaciones de la Corporación Universitaria Republicana, Bogotá, 2010, pp. 177-190; Ortíz Molina, Amanda Carolina. "Antecedentes del crédito en Colombia: los censos en la ciudad de Santa Fe en la segunda mitad del s. XVIII”, Documentos CEDE (Edición electrónica), núm. 22. Univ. De los Andes. Facultad de Economía , Bogotá, junio, 2016, pp. 1-42.

${ }^{49}$ Marchena, Juan y Garavaglia, Juan Carlos. Historia de América (Barcelona: Editorial Crítica), p. 327.

${ }^{50}$ Sobre el tema de Capellanías hay abundante bibliografía. Para este caso he consultado a: Von Wobeser, Gisela. "La actividad crediticia de instituciones eclesiásticas y de beneficencia de la ciudad de México en el siglo XVIII", en Estudios de Historia Novohispana, núm. 44, 2011, p.115. Santos Torres, Ángela. "Una aproximación económica y religiosa al funcionamiento de las capellanías de misas en la ciudad de Vélez 1720-1750”, en Anuario de Historia Regional y de las Fronteras, vol. XVII, núm. 1, 2012. pp. 45-75, ago. 2012, ISSN 2145-8499. Marulanda Restrepo, Juan S. "Instituciones eclesiásticas y crédito en Antioquia, siglo XVIII”, en Historia y sociedad, [S.1.], , núm. 31, pp. 171-203, july 2016, ISSN 2357-4720. "La economía espiritual en Antioquia. Las funciones de las capellanías entre los siglos XVII-XVIII", en
} 
¿Cómo se funda un convento? Algunas consideraciones en torno al surgimiento de la vida...

parece haber contado con sumas considerables procedentes de las dotes de las ingresantes. Si bien no podemos abordar aquí en detalle aspectos de la organización económica del convento, sí resaltamos en cambio que los presupuestos invertidos al momento de organizar las fundaciones fueron determinantes para el porvenir de los conventos. Ello se evidencia cuando se contrasta, por ejemplo, el convento de clarisas de Tunja -que al momento de su fundación cimentaba su existencia en las rentas deducidas del régimen de encomiendas- con el monasterio de la Concepción de Santa Fe que para el siglo XVIII contaba con una privilegiada situación económica basada en "el arriendo de casas y tiendas, capellanías, venta de celdas y dotes de ingreso"

En efecto, los monasterios femeninos, demandaban altos y continuos ingresos para poder mantenerse. Gran parte de su capital procedía de las dotes aportadas al momento de la profesión de las religiosas que se efectuaba con dinero en metálico o se completaba con otro tipo de bienes como propiedades urbanas, esclavos, fincas, entre otros. La extracción social de las monjas se revela como un elemento clave para la subsistencia del claustro ${ }^{52}$. Precisamente gracias a estos fondos, las religiosas podían administrar su patrimonio invirtiendo en tierras, préstamos y censos ${ }^{53}$. Es así que el convento cobraba los réditos conforme a lo convenido en contratos individuales y muchos de los beneficios provenían del arrendamiento de propiedades urbanas que se les entregaba a las monjas al momento de la profesión de una novicia.

\section{Primeros intentos de fundación del convento de monjas dominicas}

Los primeros intentos fundacionales del convento de monjas dominicas parten de la iniciativa de tres hombres notables de Santa Fe. Hernando de Caycedo, junto a sus primos Tomás Velázquez y Alonso López Hidalgo de Mayorga ${ }^{54}$. El primero de estos dos últimos era escribano de cámara de Cancillería, hermano de Fray Gerónimo Velázquez, dominico y Vicario de la provincia de San Antonino ${ }^{55}$. El segundo, Alonso López Hidalgo de Mayorga, era encomendero ${ }^{56}$. Como se verá, se trataba de vecinos

HiSTOReLo. Revista de Historia Regional y Local, [S.1.], vol. V, núm. 9, pp.12-41, jan. 2013, ISSN 2145$132 \mathrm{X}$

${ }^{51}$ Castro Vargas, Hernando, Op Cit., p. 182.

${ }^{52}$ Lavrin, Asunción. "Los conventos de monjas en la Nueva España”, en Bauer A.J. La Iglesia en la economía de América latina. Siglos XVI al XIX (México: Colección Biblioteca del INAH, 1986), p. 200.

${ }^{53}$ Los censos son contratos mediante el cual el deudor (censatario) se comprometía a pagar al censualista (obras pías) un gravamen anual (en general del 5\%) por haber recibido unos recursos determinados. El censatario debía prestar por su parte fiadores y garantías suficientes. Marulanda Restrepo, Juan S., Op Cit., p. 172.

${ }^{54}$ Archivo de Monjas Dominicas de Santa Inés, en adelante: AMDSI. Libro de los primeros años, p.1v; AGI. Cartas de Audiencias. SANTA_FE, 24, R.5, N.35.r. En un expediente sobre cobranzas de alcabalas se indica que son primos hermanos, igualmente que con Tomás de Velázquez.

${ }^{55}$ Alonso de Zamora menciona a este fraile como miembro de una de la familia de los principales de Santa $\mathrm{Fe}$, propietaria y perteneciente al alto funcionariado. Historia de la provincia de San Antonino del Nuevo Reino de Granada, tomo III (Bogotá: Biblioteca Popular de Cultura Colombiana, 1945), p. 117.

${ }^{56}$ Se mencionan sus encomiendas, heredadas por su mujer, nieta de Luis del Olmo, conquistador del Nuevo Reino de Granada. AGI. Informaciones: Alonso López de Mayorga (1627). SANTA_FE, 133, núm. 52 y 
poderosos, con múltiples actividades de orden político, militar y económico. Al capitán Hernando de Caycedo, por su parte se le referencia como "persona de muy buenas prendas naturales y adquiridas, acaudalado de nobleza y riquezas, y más de lo muy limosnero de su piadoso ánimo"57; era hijo del capitán Francisco Beltrán de Caycedo, conquistador y poblador de las ciudades mineras de Vitoria, Los Remedios, Cáceres y Zaragoza ${ }^{58}$, cuyos hijos, Francisco Beltrán y Hernando, heredaron su fortuna concentrada en minas, tierras, esclavos y casas en esas tierras de Antioquia.

Hernando Caycedo se destacó como el gran promotor del proyecto; inició las tramitaciones correspondientes para la fundación de un convento, comunicando al gobernador Juan de Borja y al arzobispo su intención para que elevaran su petición al rey reseñando las garantías económicas que se ofrecían para la obra. Según Ocáriz, se recibió cédula con fecha de 24 de diciembre de 1615 por la que la Corona solicitaba mayor información para dar curso al proyecto y que el mismo gobernador respondió confirmando su visto bueno. En efecto, encontramos reiteradamente a los tres vecinos implicados en diferentes operaciones económicas y gestiones de administración, lo que sugiere que la fundación del convento se inscribía en una iniciativa más que iban a llevar a cabo conjuntamente ${ }^{59}$. Las referencias a la posesión de bienes (tierras, encomiendas, esclavos, etc.) que concentraban, nos advierte que se trataba de personajes que además de asumir funciones vinculadas a la vida militar, o burocracia, contaban con excedentes económicos para hacer diversas inversiones.

Un ejemplo de estas diligencias se expresaba en una carta de 1608, del tribunal de cuentas de Santa Fe sobre un Juro ${ }^{60}$ que Caycedo pretendía comprar para fundar cuatro capellanías en la catedral. Mediante esta acción, le entregaría a la hacienda real, un capital por las cuatro capellanías y a cambio el rey le permitiría cobrar un porcentaje por los oficios celebrados en las distintas capillas: "Para dotar las dha capellanías pretende que V.m. se sirva de mandarle vender mil y trezientos pesos de oro de doce quilates de juro y Renta cada año alquilar a Razón de 18 U el millar"61. Las capellanías ${ }^{62}$ eran instituciones con funciones esencialmente religiosas, creadas

AGN. Encomiendas 11, D.5 (1631)

${ }^{57}$ Flórez de Ocáriz, Juan, Libro I. , Op Cit., p. 176

${ }^{58}$ AGI. Cartas de Audiencia. SANTA_FE 24,R.5.N,35

${ }^{59}$ AGN, Miscelánea: SC 39,67,D.114 (1621): “[...] Fernando de Caycedo vesino de la ciudad de los Remedios como principal deudor y Alonso López de Mayorga vesino de la ciudad de Santa Fe [...] como su fiador y principal pagador que salgo y me constituyo haciéndola deuda agena mía".

${ }^{60}$ Es una pensión perpetua sobre las rentas de la corona como pago de réditos de un capital prestado. Se distingue del censo consignativo en que el juro no pagaba alcabala, porque no se heredaba a no ser que se trate de un juro de heredad y así se especifique. Jaúregui, Luis. La Real Hacienda en Nueva España. Su administración en la época de los Intendentes. 1786-1821 (México: Facultad de Economía, UNAM, 1990, p. 30. Escriche, Joaquín. Diccionario razonado de legislación y jurisprudencia (París: Librería de Rosa, Bouret y Cia, 1852). Voz: Juro.

${ }^{61}$ AGI. Cartas y expedientes. Tribunal de cuentas de Santa Fe. SANTA_FE 52, núm.14

${ }^{62}$ Para el tema de las capellanías: Von Wobeser, Gimena, Op Cit., García Hernández, Marcela; García Hernández, Rocío M. "Las capellanías de misa en la Nueva España”, en Martínez López-Cano, Pilar. La Iglesia en Nueva España. Problemas y perspectivas de investigación”, en Serie Historia Novohispana, núm. 83, 2010, México, pp. 267-303 y Ortíz Molina, Amanda C., Op Cit. 
para rescatar las almas de los difuntos del purgatorio, creencia difundida por la Iglesia que entonces contaba con gran adhesión. Al respecto el mismo Concilio de Trento confirmó: "[...] hay purgatorio; y que las almas detenidas en él reciben alivio con los sufragios de los fieles y en especial con el aceptable sacrificio de la misa"63. La idea del purgatorio, como sitio intermedio entre el cielo y el infierno al que llegaban las almas a purificarse, promovió la necesidad de prever un tipo de "plan de salvación" en el cual se progresaba de acuerdo a la cantidad de misas oficiadas por los allegados al difunto. Esta actividad exigía la dedicación de clérigos quienes, a partir de este servicio, podían detentar un ingreso fijo que cubriera sus gastos de manutención prácticamente de por vida. Sin embargo, esta función espiritual se completaba con la utilización económica que le daba la sociedad colonial. La compra de una capellanía se hacía con un capital líquido ${ }^{64}$ que se debía mantener para garantizar la perpetuidad de la misma, razón por la cual, ese capital debía ser invertido para obtener ganancia. Es así que las capellanías se convertían en instituciones rentistas que otorgaban préstamos cuyos beneficios se destinaban a cubrir, entre otras cosas, el o los salarios del capellán. Se trataba de una institución articuladora de lo espiritual y de lo temporal y que nos da una perspectiva importante para comprender las diversas utilidades de las obras pías.

Así, desde estas mismas lógicas, debemos comprender el plan del Capitán Caycedo, cuya familia cercana a la Orden dominicana, había costeado con importantes subvenciones la construcción de la iglesia del Rosario. ${ }^{65}$ Nada extraño que la proximidad a los frailes haya animado las iniciativas por fundar el monasterio de dominicas. El proceso de petición por parte de los patronos contó con informes favorables de las autoridades de la audiencia, sin embargo, el proyecto de fundación no pudo llevarse a cabo por la repentina muerte de Hernando de Caycedo en 1622, y por la llegada del nuevo arzobispo a ocupar el obispado en sede vacante.

La llegada de Hernando Arias Ugarte -santafereño de distinguidos orígenes, con una brillante carrera como funcionario real y como arzobispo que ocuparía la silla de Santa Fe entre 1618 y 1625- representó sin embargo un verdadero revés para la fundación del convento. El nuevo arzobispo, hombre con importantes contactos en la Corte, llevaba entre sus objetivos primordiales la fundación de un monasterio de clarisas para las mujeres de su propio linaje ${ }^{66}$. Se comprende la escasa simpatía que pudo inspirar la propuesta dominica que rivalizaba con la del obispo Ugarte. Así, aunque la solicitud del convento de las dominicas llevaba ya por delante las tramitaciones exigidas, el arzobispo se inclinó por promover la licencia del rey a favor de un monasterio de clarisas.

Para el convento de Santa Clara, según Constanza Toquica en lo referente a las rentas disponibles para su fundación, el arzobispo adquirió el solar y construyó el edificio "sitio suficiente y capaz" para el monasterio. Asimismo, "el prelado donaría 40.000

\footnotetext{
${ }^{63}$ Sacrosanto y Ecuménico Concilio de Trento, Op Cit., Sesión XXV, p. 327.

${ }^{64}$ Ortíz Molina, Amanda, Op Cit., 4.

${ }^{65}$ Zamora, Fr. Alonso de OP., Op Cit., 143.

${ }^{66}$ Toquica, Constanza, Op Cit., p. 70.
} 
patacones a la fundación y dotación del convento" que se pondrían a renta; la institución contaría además con el respaldo de los bienes y ganancias que en adelante fuera a adquirir el hermano del arzobispo, Diego, quien quedó como patrón del convento ${ }^{67}$. Lo anterior revela las tensiones internas de la sociedad colonial. Las relaciones con la Corte y los antecedentes del obispo Arias Ugarte jugaron un papel decisivo para los permisos de apertura del convento, considerando que los fondos donados, de hecho, eran más o menos similares a los ofrecidos por Caycedo.

No menos importante para entender el revés de la propuesta dominica resultó el inesperado fallecimiento del Capitán Caycedo. Este obligó a organizar su legado en razón del nacimiento de un hijo póstumo que descontaba el capital inicial previsto para el monasterio. Sus albaceas, su hermano Francisco Beltrán Caycedo y su cuñado Francisco de Berrío, también gobernador, dispusieron de la herencia para dos capellanías de "1000 patacones de renta cada una añal" dejando de lado las cuatro con las que tenía obligación de 400 y 200 p. a cada Patrón ${ }^{68}$. De la fortuna legada por Hernando de Caycedo, su hermano y albacea

[...] intentó vender los bienes que quedaban por fin [...] minas, negros, tierras, herramientas y demás haciendas que se remataron en la ciudad de los Remedios y Antiochia por el valor de 53.000 p. de oro de veinte quilates y remitió un legado de 10.000 ducados que había hecho su hermano a Doña Gerónima Catalina Caycedo, su hija y las compró el mismo por remate ${ }^{69}$.

No obstante, los reveses señalados, sus primos López de Mayorga y Velázquez insistieron en la solicitud de licencia del convento y ofrecieron 7.000 patacones cada uno; esto animó a Francisco Beltrán Caycedo, quien decidió aportar 10.000 pesos $^{70}$ de su fortuna y 19.000 pesos de la fortuna de su hermano aún pendiente de ser distribuida. Junto a este capital incluía además a los capellanes (con obligaciones de sufragio a favor de Hernando), lo que sumaría un total de 45.000 pesos.

Cuadro 2. Donaciones para la Fundación del Convento de Dominicas.

\begin{tabular}{|l|c|}
\hline \multicolumn{1}{|c|}{ Donante } & Cantidad (en pesos) \\
\hline Alonso López de Mayorga & 7.000 \\
\hline Tomás Velázquez & 7.000 \\
\hline Francisco B. Caycedo & 10.000 \\
\hline Herencia de Hernando Caycedo & 19.000 \\
\hline Capellanías de H. Caycedo $(+)$ & 2.000 \\
\hline Total & $\mathbf{4 5 . 0 0 0}$ \\
\hline
\end{tabular}

\footnotetext{
${ }^{67} \mathrm{Ibid}$.

${ }^{68}$ AMDSI. Libro Primeros Años. 1v. Aunque aquí no se especifica más, es posible que se refiera a la modificación de las cuatro capellanías de la Catedral a las que hicimos mención.

${ }^{69}$ AGI. Cartas de Audiencia. SANTA_FE, 24,R.5,N.35

${ }^{70}$ La unidad con que usualmente se hacían los pagos en la América española fue el peso fuerte de plata: un peso equivalía a ocho reales. Asimismo, el patacón era una moneda de ocho reales. Cfr. Hernández Gamarra, Antonio. "Las especies monetarias en Colombia", en Revista Credencial Historia, BogotáColombia, junio 2002, Edición 150, Biblioteca Virtual Luis Ángel Arango.
} 
¿Cómo se funda un convento? Algunas consideraciones en torno al surgimiento de la vida...

La nueva propuesta se elevó a la Audiencia el 30 de junio de 1622, sin respuesta alguna por parte de la Corona; ésta, por el contrario, conforme a lo que analizamos, aprobó la construcción del monasterio de las clarisas del obispo Arias; este último se culminó en $1629^{71}$.

El interés por la apertura de un convento de dominicas iba más allá del anhelo de unos varones adinerados de la sociedad. Tras él se perciben también otros intereses no tan visibles en las fuentes. En particular, detrás de esta fundación, estaban los frailes dominicos. Esta orden mantenía fuertes lazos con la sociedad laica y, como se verá con la fundación del convento de Santa Inés, gozaba de una fuerte ascendencia en la élite local. Esta perspectiva, observada por Plata Quezada ${ }^{72}$, nos ha guiado en la comprensión del proceso fundacional, pues la lectura de los documentos, permite reconocer en la trastienda la incidencia de los frailes en la decisión de los feligreses que resultaron futuros fundadores.

Para el período, las órdenes religiosas de franciscanos, dominicos, agustinos y jesuitas tenían ya una presencia consolidada en la ciudad tanto en número de conventos como en frailes. Los regulares desempeñaban un papel muy destacado no sólo con el ejercicio del ministerio, sino con su actividad apostólica. Mediante la evangelización y predicación promovieron la adhesión de los fieles, la cercanía a los conventos, la creación de cofradías, la expansión de las devociones propias de cada institución y también el sustento económico de las mismas. Estos aspectos expresaban el éxito corporativo de la familia religiosa ${ }^{73}$ y su valoración social.

Para los dominicos, como para el resto de las congregaciones regulares, erigir todos los estamentos de la comunidad religiosa les daba una fuerte conciencia de representación y, aunque no era la única razón de auspicio de las fundaciones de conventos de monjas, sí consideramos el interés de los frailes por el establecimiento de conventos bajo advocaciones que remitían a sus respectivas familias religiosas.

\section{Fundación del Monasterio de Santa Inés. La familia Chávez}

Todas las referencias al surgimiento del monasterio de Santa Inés ${ }^{74}$ nos sitúan en el convento de frailes dominicos donde, en un principio, fue a realizar sus "ejercicios espirituales" Juan Clemente de Chávez, antes de asumir su nuevo destino como gobernador de una provincia de Antioquia. El prior del convento le proporcionó para su oración un libro de devociones dominicas ${ }^{75}$ donde reparó en la lectura de la vida de

\footnotetext{
${ }^{71}$ Flórez de Ocáriz, Juan, Op Cit.

${ }^{72}$ Plata Quezada, W., Op Cit, p. 130

${ }^{73}$ Rubial García, Manuel. "Los conventos mendicantes", en Gonzalbo Aizpuru, Pilar, Historia de la Vida cotidiana en México. Tomo II (México: La ciudad Barroca, Colmex, FCR, 2005), p.169.

${ }^{74}$ Florez de Ocáriz, Juan, Op Cit. Libro I 176. AMDSI: Constituciones y primeros años del Convento (1689); Libro de Profesiones de las Monjas de Santo Monasterio de Señora Santa Inés.

${ }^{75}$ Se trataba del libro La Crónica de la religión. "Pudo tratarse de la obra constituida por cinco partes titulada La historia general de santo Domingo y de su Orden de Predicadores [...] cuyas primeras dos
} 
una monja dominica, Inés de Montepulciano: [...] que le ocupó las potencias del alma para tenerla por abogada deseando fundar convento de religiosas con su nombre ${ }^{76}$.

Chávez, miembro de una familia que se anotaba entre los conquistadores y primeros pobladores del territorio de Santa Fe, podía considerarse un destacado miembro de la elite; había sido alférez real y alcalde ordinario y le distinguía su cercanía al convento de Santo Domingo ${ }^{77}$. En efecto, el 29 de mayo de 1628 dispuso en su testamento -tras una confesión con Fray Antonio de León, prior del convento del Rosario- el legado de sus propiedades para la fundación de un convento dedicado a Santa Inés de Montepulciano. En el documento se estableció que sus bienes se unirían a los de su hermana Antonia para concretar la apertura de la nueva casa religiosa.

A los hermanos Chávez, la vida religiosa femenina no les resultaba ajena. Dos de sus hermanas, Beatriz de la Concepción (ya mencionada anteriormente) y Ana de San Jerónimo, estaban en el convento de la Concepción, donde habían desempeñado diferentes oficios; incluso Beatriz había sido abadesa de dicho monasterio. De manera que Juan Clemente y Antonia estaban al tanto de lo que implicaba llevar adelante una institución de esas características. Esto se constata en una carta de 1618, en la que Juan Clemente servía de testigo a las monjas en la citada petición al rey por la reasignación de las medias anatas ${ }^{78}$. En su declaración dejó asentado que conocía las necesidades del monasterio y las urgencias del edificio. Allí mismo detallaba las mejoras a llevar a cabo en el recinto tales como agrandar el coro, construir dormitorios o dotarlo de una enfermería. Incluso se refirió a la situación económica del monasterio, al afirmar que la renta de las dotes no alcanzaba a cubrir los gastos de manutención, vestimenta y reparaciones básicas de dicha residencia: "[...] Y las dhas rentas que estaban impuestas a catorce mil el millar se an ydo y ban redimiendo y con la nueva ymposicion de a veinte mil el millar se aminorado mucha parte con que se augmenta la dicha necesidad"79.

Posiblemente su familiaridad con el estilo de vida conventual alentó su decisión de fundar un nuevo convento al que entrarían sus dos hermanas, monjas de la Concepción; éstas dejarían su claustro inicial e ingresarían al de Santa Inés en carácter de fundadoras junto a otras mujeres de la propia familia ${ }^{80}$. Juan Clemente, sin embargo, no pudo ver realizado su deseo. Al poco tiempo de concretar el testamento y de asumir como

partes fueron escritas por fray Hernando del Castillo y publicadas en Valladolid en 1613. Ejemplares de estas obras en las ediciones mencionadas se encuentran hoy en el Convento san Alberto Magno de la orden de Predicadores de Bogotá". Acosta Luna, Olga; Vargas Murcia, Laura. 2012 (p. 19)

${ }^{76}$ AMDSI. Libro de Constituciones, 2v

${ }^{77}$ AGI. SANTA_FE,133,núm. 11.1v: "Juan Clemente de Chaves [...] digo que por mi parte que es hijo legítimo del Capitán Juan de Chaves y de Doña Eufracia de Santiago [...] y que el dicho capitan Juan de Chaves vino a este Reino en compañía del adelantado Don Alonso Luis de Lugo, gobernador y capitán general [...] y después milito a su costa con sus armas, caballos y criados y se hallo en las conquistas y poblaciones del valle de Guatavita, ciudades de Tocayma Ybague y valle de la Plata".

${ }^{78}$ AGI: SANTA_FE 131, núm.5.1v.

${ }^{79}$ AGI: SANTA_FE 131, núm.5.2r.

${ }^{80}$ AMDSI. Libro de los primeros años. 1r 
¿Cómo se funda un convento? Algunas consideraciones en torno al surgimiento de la vida...

gobernador de Zaragoza (Antioquia) murió. Según dispuso, sus bienes se destinarían al futuro convento y su hermana Antonia de Chávez, su heredera y albacea, debía llevar adelante la obra de construcción del claustro del que ella misma sería la patronafundadora. ${ }^{81}$ En efecto, la única heredera con capacidad de gestionar la herencia y los bienes de la familia era Antonia, dado que sus dos hermanos varones habían fallecido y sus otras dos hermanas, Beatriz y Ana, eran religiosas. ${ }^{82}$

Antonia -a su vez viuda de Lope de Céspedes de quien heredó la encomienda de los indios de Ubaqué y Cáqueza ${ }^{83}$ - hizo la petición al Consejo, informando de acuerdo a los requisitos que exigía el patronato, que contaban con todos los medios para llevar adelante la fundación. Para construir el convento destinaba la casa familiar y anexaba una propiedad colindante que le permutó a una prima por una casa "en la calle la carrera" ${ }^{84}$ para disponer de mayor perímetro. Así, como expresaba en un documento del 14 de julio de 1630 ,

[...] pretendo fundar un convento de monjas dela advocación de Sancta Ynes de Monte Policiano para lo qual doy y dono todas mis haciendas y del dho mi hermano en oro, estancias y ganados esclavos y otros bienes en mucha cantidad de pesos que son mas de sesenta mil ${ }^{85}$.

Al respecto ilustran y complementan otros documentos del Archivo de Indias, elevados al Consejo por parte del provincial dominico fray Tomás Vaca ${ }^{86}$; los mismos señalan que para la fundación se dispuso de dos grandes propiedades destinadas a la edificación del convento y la iglesia, dos casas debajo de la plaza mayor, dieciocho mil pesos en dinero efectivo, además de estancias de pan coger, cuarenta estancias con ganado mayor y menor en la sabana de Bogotá y cinco haciendas de trapiche en Tocaima, en "tierra caliente", con 20 esclavos. También se aportaron mil pesos de beneficio de la renta de las encomiendas que se destinarían para la fábrica del convento, es decir para el sostenimiento del edificio, más los gastos que ocasionaban los insumos del culto como velas, aceite y gastos de sacristía, entre otros.

Se evidencia en la información citada las dimensiones de esta "empresa". Solo para iniciar un proyecto de fundación se debía contar con una base económica capaz de afrontar los gastos de construcción, más los de aprovisionamiento del edificio conforme a su función. Las dependencias del convento debían contar con tornos, locutorios, cocina, dormitorios, refectorio, enfermería, oficinas, muros y $\operatorname{cercas}^{87}$; la parte correspondiente a la iglesia debía a su vez contar con altares, ornamentos,

\footnotetext{
${ }^{81}$ AMDSI. Transcripción del Testamento de Don Juan Clemente de Chávez del 29 de mayo de 1628 (con fecha de 1769 a causa de un pleito en Boyacá por una propiedad)

${ }^{82}$ Flórez de Ocáriz, Juan, Op Cit., Libro II. 1676. p. 385.

${ }^{83}$ Encomienda confirmada en 3/5/1608. AGI. SANTA_FE,164,N.14

${ }^{84}$ Ibid., $3 \mathrm{r}$.

${ }^{85}$ AMDSI. Libro de Fundación del Convento de Santa Inés .28r.

${ }^{86}$ AGI, SANTA_FE,134, núm.23 1r.

${ }^{87}$ AMDSI. Libro de los primeros años... 3r
} 
sacristía, rejas, coros, campanas y otros elementos igualmente $\operatorname{costosos}^{88}$; los revestimientos de la capilla y los enseres de sacristía (como vasos de oro y plata, sagrario, custodia, alhajas, imágenes, ropa de buenos géneros, mobiliario, etc.) eran artículos prácticamente de lujo. Al respecto, señala la documentación, que:

$[\ldots]$ tiene el dinero para dha fundación y no para otra cosa dieciocho mil pesos a ocho reales depositado para este efecto en el padre presentado Fray Cristoval Gallego, prior de este convento de Santa Fe para fabrica, casa con clausura, Yglesia a satisfacción de vuestro gobernador y arzobispo de este rreyno para numero de cinquenta monjas ${ }^{89}$.

Asimismo, los conventos demandaban una serie de gastos fijos que debían de ser atendidos en cuanto se fueran a habilitar y tuvieran las monjas dentro. Por esta razón previamente debían justificarse los recursos para obtener la licencia de apertura. En todas las casas religiosas se contaba con el ingreso que aportaban las dotes de las monjas al momento de hacer la profesión. En el caso del convento de Santa Inés, se estipuló una población de 50 monjas (luego se redujo a 33) de velo negro o "de coro" categoría que se destinaba a las hijas legítimas, de familias notables y prestantes, que debían pagar para ingresar algo más de 2.000 pesos (se incluía también propinas y ajuar más 100 pesos para alimentos del año de noviciado). La otra categoría de ingreso eran las monjas de velo blanco, llamadas legas o de obediencia, pertenecientes a otra condición económica y social. Su vida en el monasterio implicaba cumplir con trabajos y servicios. Su dote se estableció en 400 pesos, ajuar de dos hábitos y ropa de cama y contaban con un cupo para 12 monjas $^{90}$.

El patronato del convento de Santa Inés disponía de todas las condiciones necesarias para fundar un convento, como era un solar apropiado y el capital para la construcción y dotación material. Por otro lado, los fondos económicos que sostendrían a la institución provendrían de las haciendas aportadas por la familia Chávez. Como se ha dicho, se trataba de explotaciones agrícolas y ganaderas diversas y además, se contaría con los ingresos aportados por las rentas de las encomiendas. La base económica para la fundación y sostenimiento del convento, a diferencia de los otros conventos de la ciudad, derivarían fundamentalmente del campo ${ }^{91}$. Así lo previno el mismo gobernador Chávez en su testamento: "[...] y mediante que en las dichas tierras con el favor de su divina Magestad pueden cogerse y criarse cantidad de todos los frutos y ganados que acá hay y que con ellos se pueden sustentar muchas religiosas" Tratándose de una cuantiosa fortuna, cabe preguntarse los motivos que llevaron a los hermanos Chávez a darle ese fin a la herencia familiar. Al respecto, los notables de la ciudad que presentaron su testimonio a favor de la fundación destacaban la relevancia

\footnotetext{
${ }^{88}$ AMDSI. Libro de Fundación ... 44v.

${ }^{89}$ AGI. SANTA_FE 134, núm. 23 2v.

${ }^{90}$ AMDSI. Libro de Fundación ... 44v.

${ }^{91}$ Desde este punto de vista se plantean futuros estudios que analicen la proyección económica del convento de Santa Inés y que intentará sumarse a otros estudios de instituciones monásticas en el Nuevo Reino de Granada.

${ }^{92}$ AMDSI. Transcripción del testamento de Dn. Juan Clemente de Chávez 2r.
} 
de la fundación no solo por el valor social que representaba, sino por el aprecio con que contaba esta destacada familia. ${ }^{93}$ El monasterio, como se advertía en otros casos, les aseguraba a los padres de familia un sitio adecuado para la conservación del honor y la limpieza étnica. En la sociedad colonial se prefería el encierro al mestizaje de las hijas de los principales. No obstante, creemos que no sólo el sentido social fue lo que motivó semejante inversión; un monasterio era una empresa que abarcaba muchos aspectos de la vida y el manejo de estas instituciones implicaba un esfuerzo corporativo a cargo inmediato de la fundadora, de su familia y de las propias monjas. Quizás tampoco fuera arriesgado pensar lo que pasaba por la mente de los patronosfundadores, y encontrarnos con razones que apunten a la creación de una entidad piadosa que concentrara el patrimonio de los Chávez que no contaba con herederos directos. ${ }^{94}$ La dimensión espiritual y material una vez más tejieron un puente que permitía a estos hermanos piadosos y pudientes alcanzar el favor de Dios, obtener reputación social e invertir sus finanzas en una obra que continuamente proporcionaría beneficios económicos y protección divina para los vivos y difuntos de la familia.

[...] para que Dios sea servido y alabado por ella y por las siervas suyas que en este convento vivieren y nuestras almas hallen misericordia delante de su divina magestad, a cuyos pies ponemos nuestras haciendas y con ellas nuestros corazones y almas" 95 .

La cédula de aprobación llegó el 2 de noviembre de 1638 y el monasterio abrió sus puertas el 19 de julio de 1645. En carácter de fundadoras entraron Beatriz de la Concepción y su prima hermana, Francisca Eufrasia de Cristo, ambas provenientes del convento de la Concepción, pues Ana de San Gerónimo había fallecido para entonces. Ambas mujeres, con experiencia en vida conventual, se sucedieron en el gobierno puesto que así lo indicaban las constituciones para el caso de que las monjas sean de la familia Chávez. Junto a las fundadoras ingresaron diez doncellas eximidas de pagar la dote merced determinada por los patronos que se destinaba a las mujeres de la propia familia. Esto implicaba que en principio dichas dotes no eran para beneficencia, sino que -esta especie de beca en la actualidad- se destinarían a las candidatas elegidas por los fundadores. El ingreso al claustro sin obligación de dote era un privilegio que se reservaba a las mujeres del linaje para que con ese capital invertido alcanzaran virtud y santidad.

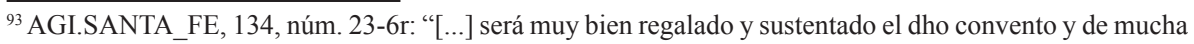
autoridad por aver de entrar por fundadora Dña Antonia de Cháves y sus hermanas [...] personas de mucha calidad y gobierno y de esto será Nto Señor muy servido y resultará mucha utilidad a esta ciudad las demás de este reyno[...]”, (Testimonio del vecino Francisco Benegas Ponce de León).

${ }^{94}$ Coehlo Nascimento, María Filomena. "Casadas con Dios, linajes femeninos y monacato en los siglos XII y XIII”, en Historia de las mujeres en España y América, vol. I, Cátedra. Madrid, 2005, p. 698. La autora menciona como motivación a las fundaciones conventuales femeninas la posibilidad de aprovisionamiento patrimonial del linaje fundador que usaría el monasterio como intermediario en sus proyectos.

${ }^{95}$ AMDSI. Transcripción del Testamento 3r.
} 


\section{Consideraciones finales}

Durante la primera mitad del siglo XVII se realizaron las fundaciones de la mayoría de los conventos de monjas de la ciudad de Santa Fe. Esto obedecía a la necesidad de disponer de recintos custodiados para alojar a las mujeres apartadas de la nupcialidad. La aparición de estas instituciones revela las tensiones de la sociedad colonial; en particular, se aprecia un binomio espiritual y material en el que confluían numerosos intereses que beneficiaban a los propulsores de las obras. Los constituidos patronos, según la mentalidad de entonces, no sólo acercaban su alma a Dios, sino que acrecentaban su prestigio personal. Quizás, tan importante como lo anterior, resultaba la fundación de una empresa con capacidad de préstamo y socorro financiero para los que compartían su mismo status social.

Se percibe, asimismo, cómo el alcanzar la gracia divina y la carrera por la salvación del alma motivaron gran parte de la actividad económica en el periodo; para estos fines se destinaron cuantiosos recursos. Fundar un convento, considerada una opción dentro de la categoría de las obras pías, exigía una inversión económica de gran tamaño. Sin embargo, este tipo de iniciativas advierten no sólo del interés religioso de la sociedad, sino también la consolidación de Santa Fe como ciudad. En efecto, su élite parecía complacida de superar las primeras instancias de asentamiento, demostrando que estaba en condiciones de resolver el problema de las mujeres marginadas del matrimonio, asegurando también su resguardo y educación; aspectos estos últimos que los conventos atenderían.

Así, el primer convento femenino fundado en Nueva Granada, el de las Clarisas de Tunja, revela un esquema por el que pasarán las siguientes fundaciones: el interés de un vecino devoto, un solar determinado, la disponibilidad económica, la justificación y tramitaciones respectivas antes las autoridades locales (gobernador y obispo), y los informes que estos enviarían a la Península para su aceptación o no. Sin embargo, estas instituciones se diversificaron, no sólo por la orden religiosa a la que se incorporaban -aunque este aspecto no fue tan determinante en los primeros años-, sino por las condiciones económicas de cada convento. Los montos o bienes legados por los respectivos fundadores o patronos formaban parte del capital inicial de cada convento que debía de ser administrado por los designados como sucesores, encargados de llevar a cabo las cargas económicas de la fundación. En el caso del convento de la Concepción es evidente que contó con ciertos privilegios de la Corona al quedar bajo su patronazgo; en este sentido, esta fundación no quedó adscripta a una familia, lo que sin dudas le aportó márgenes de libertad para efectuar transacciones más beneficiosas. Posiblemente este es uno de los aspectos que explica el auge económico y prestigio social que detentó la Concepción por casi todo el siglo XVII.

Se observa en esta investigación que los fondos destinados a la fundación de un convento representaban generalmente los mismos gastos, rondando los 50 mil pesos. Sin embargo, lo importante al momento de iniciar la fundación era destacar cuáles serían los bienes capaces de solventar dichas instituciones a futuro. El largo proceso de fundación del monasterio de Santa Inés, con un primer intento muy avanzado en las 
tramitaciones y sin embargo interrumpido, sugiere que estas instituciones para surgir, además de los aportes económicos, eran dependientes de las instancias de poder como la del obispo Arias de Ugarte. La tenacidad de algunos frailes predicadores y su interés corporativo, sin embargo, promovieron el segundo y definitivo intento de fundación que quedó en manos de una familia muy pudiente que destinó el grueso de su fortuna para resguardar especialmente a las mujeres de su propio linaje. La cuantiosa herencia dejada por Antonia de Chávez se basaba en la posesión de encomiendas, de tierras, de ganado y de un trapiche que aseguraba la subsistencia de unas cincuenta monjas conforme a lo establecido por sus fundadores-patrones.

Un convento constituía un esfuerzo económico que implicaba grandes capitales y por tanto se destinaba a personajes de las elites con posibilidad de inversión, que constituían la síntesis económica y espiritual que se aludía arriba. Las similitudes observadas en los procesos fundacionales no impiden apreciar a su vez las diferencias que existen en cada una de los claustros estudiados. La vida en clausura y el monacato femenino en general exigen nuevas miradas que permitan revelar la complejidad de su surgimiento en un contexto como el de las ciudades americanas del siglo XVII.

\section{Fuentes}

\section{Fuentes Primarias}

\section{Archivos}

Archivo de Monjas Dominicas de Santa Inés (Bogotá), Libro de la fundación de Monasterio (1645).

Archivo de Monjas Dominicas de Santa Inés (Bogotá), Libro de las constituciones. Historia de los primeros años del convento (1689).

Archivo de Monjas Dominicas de Santa Inés (Bogotá), Libro de profesiones de las monjas de Santo Monasterio de Señora Santa Inés.

Archivo de Monjas Dominicas de Santa Inés (Bogotá), Transcripción del testamento de Dn Juan Clemente de Chávez del 29 de mayo de 1628 realizada en 1769 debido a un pleito de pertenencia de un pantano en el Valle de Boxacá.

Archivo General de Indias, CONTRATACION 5217 A, núm. 5.

Archivo General de Indias, SANTA_FE, 60, núm. 26.

Archivo General de Indias, SANTA_FE, 131, núm. 5.

Archivo General de Indias, SANTA_FE, 133, núm. 11. 
Archivo General de Indias, SANTA_FE, 134, núm. 23.

Archivo General de Indias, SANTA_FE, 24, R.5, núm. 35.

Archivo General de Indias, SANTA_FE 52, núm. 14.

Archivo General de Indias, SANTA_FE, 164, núm. 14.

Archivo General de la Nación (Colombia), Capellanías-Cundinamarca: CAPELL-C/ MARCA:SC.9,1, D.24. 729 r

Archivo General de la Nación (Colombia), Miscelánea: SC 39,67, D.114

\section{Fuentes primarias editadas}

Flórez de Ocáriz, Juan. Genealogías del Nuevo Reino de Granada. Libro I. Joseph Fernández de Buendía. Madrid: Impresor de la Real Capilla de su Magestad, 1674.

Flórez de Ocáriz, Juan. Genealogías del Nuevo Reino de Granada. Libro II. Joseph Fernández de Buendía. Madrid: Impresor de la Real Capilla de su Magestad, 1676.

Recopilación de leyes de los Reynos de las Indias. Libro I, Título III. De los Monasterios de Religiosos y Religiosas hospicios y recogimientos de huérfanas, Julián de Paredes. Madrid, 1681.

Sacrosanto y Ecuménico Concilio de Trento. Sesión VI. Capítulo XVI. Barcelona: Imprenta de Benito Espona, 1845.

Zamora, Fr. Alonso de OP. Historia de la provincia de San Antonino del Nuevo Reino de Granada. Bogotá: Biblioteca Popular de Cultura Colombiana, 1945. Tomos I, II, III

\section{Fuente secundaria}

\section{Libros}

Acosta Luna, Olga Isabel y Vargas Murcia, Laura Liliana. Curadoras. Una vida para contemplar. Serie Inédita: vida de Santa Inés de Montepulciano OP. Museo Colonial. Bogotá. 2011.

Aldea Vaquero, Quintín; Marín Martínez, Tomás y Vives Gatell, José. Diccionario de Historia eclesiástica de España. Madrid: Instituto Enrique Flórez, CSIC, 1973.

Álvarez Gómez, Jesús. Historia de la Vida religiosa T. III. Desde la Devotio Moderna al Concilio Vaticano II. Madrid: Ediciones Paulina, 2da edición, 2002. 
¿Cómo se funda un convento? Algunas consideraciones en torno al surgimiento de la vida...

Escriche, Joaquín. Diccionario razonado de legislación y jurisprudencia. París: Librería de Rosa, Bouret y Cia, 1852.

Jáuregui, Luis. La Real Hacienda en Nueva España. Su administración en la época de los Intendentes. 1786-1821. México: Facultad de Economía, UNAM, 1999.

Matilla, Luis Carlos. Las concepcionistas en Colombia (1588-1990). Bogotá: Editorial Kelly, 1992.

Mayoralgo y Lodo, José Miguel. Historia del régimen jurídico de los títulos nobiliarios. Manual de Nobiliaria I. Madrid: Ediciones Hidalguía, 2007.

Ortiz Molina, Amanda. Antecedentes del crédito en Colombia: los censos en la ciudad de Santa Fe en la segunda mitad del s. XVIII, Documentos CEDE, Edición electrónica, núm. 22, Universidad de los Andes, Facultad de Economía, Bogotá, junio 2016.

Plata Quezada, William E. Vida y muerte de un convento. Dominicos y sociedad en Santafé de Bogotá (Colombia) siglos XVI-XIX. Salamanca: San Esteban Editorial, 2012.

Sánchez Lora, José L. Mujeres, conventos y formas de religiosidad barroca. Fundación Universitaria Española. Madrid, 1988.

Teruel Gregorio de Tejada, Manuel. Vocabulario básico de la historia de la Iglesia. Barcelona: Crítica, 1993.

Toquica, Constanza. A falta de oro: linaje, crédito y salvación. Una historia del Real convento de Santa Clara de Santa Fe de Bogotá siglos XVII y XVIII. Bogotá: Universidad Nacional de Colombia, Minst. de Cultura. Inst. Colombiano de Antropología e Historia, 2008.

Vila Enriqueta, Lourdes Kuethe. Boletín de la Real academia Sevillana de Buenas Letras, Minervae Baeticae, núm. 34, 2006.

Von Wobeser, Gisela y Vila Vilar, Enriqueta. Muerte y vida en el más allá. España y América. Siglos XVI-XVIII. México: UNAM, 2009.

\section{Capítulos de libro}

Coelho Nascimento, María Filomena. "Casadas con Dios, linajes femeninos y monacato en los siglos XII y XIII", en Historia de las mujeres en España y América Latina, vol I. Madrid: cátedra. 2005. 
Elliott, J. H. “España y América en los siglos XVI y XVII”, en Bethell Leslie (ed.), Historia de América Latina. 2. América Colonial: Europa y América en los siglos XVI, XVII, XVIII, capítulo 1.

García Hernández, Rocío M. "Las capellanías de Misas en la Nueva España”, en Martínez López-Cano, Pilar, La Iglesia en Nueva España. Problemas y perspectivas de investigación, núm. 83. México: Serie Historia Novohispana, 2010.

Huerta Ourcel, Magdalena y Sarabia Viejo, María Justina. "Establecimiento y expansión de la Orden Concepcionista en México; siglo XVI", en La orden concepcionista. Actas del I Congreso Internacional. León, 1990.

Lavrin, Asunción: "Los conventos de monjas en la Nueva España", en Bauer A.J. La Iglesia en la economía de América latina. Siglos XVI al XIX. México: Colección Biblioteca del INAH, 1986.

Levaggi, Abelardo. "Papel de los patronos en las capellanías. Cuestiones suscitadas a su respecto en el río de la Plata”, en Martínez López-Cano, Pilar, La Iglesia en Nueva España. Problemas y perspectivas de investigación, núm. 83. México: Serie Historia Novohispana, 2010.

Lohmann Villena, Guillermo y Vila Vilar, Enriqueta. "La emigración familiar a América, los Almonte", en Gonzalbo Aizpuru, Pilar (coord.), Familias Iberoamericanas, Historia Identidad y Conflictos. México: Colegio de México, 2001.

Rubial García, Antonio. "Los conventos mendicantes", en Gonzalbo Aizpuru, Pilar, Historia de la Vida cotidiana en México, tomo II. México: La ciudad Barroca, Colmex, FCE. 2005.

Sánchez Hernández, Ma. Leticia. "Servidoras de Dios leales al Papa. Las monjas de los monasterios reales", en librosdelacorte.es, Monográficos 1, Año VI, 2014, ISSN 1989-6425.

\section{Artículos de revista}

Castro Vargas, Hernando. "Jerarquías sociales y relaciones políticas, el convento de la Concepción de Bogotá y la ejecución de censos (1739-1810)", en Revista Republicana, núm. 8, enero-junio 2010, Centro de Investigaciones de la Corporación Universitaria Republicana.

Coelho Nascimento, María Filomena. "Casadas con Dios, linajes femeninos y monacato en los siglos XII y XIII”, en Historia de las mujeres en España y América Latina, vol I. Madrid: cátedra. 2005.

Colmenares, Germán. "Censo y Capellanías: formas de crédito en una economía agrícola”, en Cuadernos Colombianos, núm. 2, 1974. 
¿Cómo se funda un convento? Algunas consideraciones en torno al surgimiento de la vida...

Hernández Gamarra, Antonio. "Las especies monetarias en Colombia", en Revista Credencial Historia, junio 2002, edición 150, Biblioteca Virtual Luis Ángel Arango, Bogotá, Colombia.

Marulanda Restrepo, Juan S. "La economía espiritual en Antioquia. Las funciones de las capellanías entre los siglos XVII-XVIII", en HiSTOReLo. Revista de Historia Regional y Local, [S.1.], vol. V, núm. 9, jan. 2013, ISSN 2145-132X.

Marulanda Restrepo, Juan S. "Instituciones eclesiásticas y crédito en Antioquia, siglo XVIII”, en Historia y sociedad [S.1.], núm. 31, july 2016, ISSN 2357-4720.

Santos Torres, Ángela. "Una aproximación económica y religiosa al funcionamiento de las capellanías de misas en la ciudad de Vélez 1720-1750", en Anuario de Historia Regional y de las Fronteras, vol. XVII, núm 1, ISSN 2145-8499, 2012.

Von Wobeser, Gisela y Vila Vilar, Enriqueta. "La actividad crediticia de instituciones eclesiásticas y de beneficencia de la ciudad de México en el siglo XVIII", en Estudios de Historia Novohispana, núm. 44, 2011.

\section{Otros}

De la Corte Navarro, Inmaculada. "Aportaciones reales a los conventos de monjas en México", en Memorias del II Congreso Internacional del Monacato femenino en el Imperio español. México: Centro de estudios de historia de México, 1995. 